\title{
Performance evaluation of sigle row manual cotton planter
}

\author{
U.S. KANKAL, D.S. KARALE, V.P. KHAMBALKAR AND S.H. THAKARE
}

Received : 18.12.2015; Revised : 12.02.2016; Accepted : 07.03.2016

See end of the Paper for authors' affiliation

Correspondence to :

\section{U. S. KANKAL}

Department of Farm Power and Machinery, College of Agricultural Engineering and Technology, Dr. Panjabrao Deshmukh Krishi Vidyapeeth, AKOLA (M.S.) INDIA
-ABSTRACT : A proper placement of seed in field is most important operation in order to obtain optimum yield of crop. Day by day the land fragmentation was increased and which resulted near about 65 pre cent of the land holders are small and marginal land holding capacity in the region. Considering the limitations due to costly seed, traditional method of manual dibbling, labour shortage and small marginal land holding pattern there is need of small manual planter for small and marginal land holders. In view of the above, the manually operated seed planter was tested at Deptt. of Farm Power and Machinery, Dr. Panjabrao Deshmukh Krishi Vidyapeeth, Akola. A single row cotton planter was evaluated for performance by conducting laboratory and field tests. In laboratory test calibration of planter for seed rate, uniformity of seed planting and percentage of seed damage was determined at three cell plate, two gear ratio and level of seed in hopper. Based on the laboratory test cell plate, gear ratio and level of seed in hopper were selected for field test. The three trials of planter were taken for planting Bt-cotton crop. The field tests comprised of determination of effective field capacity, average depth of placement of seeds in the furrows and mean spacing of seeds within each row. The rate of work was observed to be in the range of 0.18 to $0.21 \mathrm{ha} / \mathrm{h}$ at forward speed of 2.24 to $2.5 \mathrm{~km} / \mathrm{h}$ in well prepared seed bed along with the opened furrows. The average depth of planting was observed in the range of $4.5 \mathrm{~cm}$ to $5 \mathrm{~cm}$. The field efficiency of the planter was observed in the range of 88.88 to 91.1 per cent.

- KEY WORDS : Cotton, Planter, Performance evaluation, Field tests, Spacing, Depth, Efficiency

— HOW TO CITE THIS PAPER : Kankal, U.S., Karale, D.S., Khambalkar, V.P. and Thakare, S.H. (2016). Performance evaluation of sigle row manual cotton planter. Internat. J. Agric. Engg., 9(1) : 19-26. 